\title{
Kore Kadınının Moderleşme Süreci ve Ulusal \\ Hareketinin Tarihi
}

\section{The History of Korean Women's National Modernization Movement}

\author{
Eun Kyung JEONG ${ }^{1}$
}

'İstanbul Üniversitesi, Edebiyat Fakültesi, Doğu Dilleri ve Edebiyatları Bölümü, Kore Dili ve Edebiyatı Anabilim Dalı, İstanbul, Türkiye

Sorumlu yazar/Corresponding author: Eun Kyung JEONG (Dr. Öğretim Üyesi), Istanbul Üniversitesi, Edebiyat Fakültesi, Doğu Dilleri ve Edebiyatları Bölümü, Kore Dili ve Edebiyatı Anabilim Dalı, İstanbul, Türkiye E-posta: eunkyung.jeong@istanbul.edu.tr

Başvuru/Submitted: 16.11 .2020

Revizyon Talebi/Revision Requested:

11.12.2020

Son Revizyon/Last Revision Received:

25.12.2020

Kabul/Accepted: 13.02.2021

Atıf/Citation: Jeong, Eun Kyung. "Kore Kadınının Moderleşme Süreci ve Ulusal Hareketinin Tarihi", Şarkiyat Mecmuası - Journal of Oriental Studies 38 (2021), 67-87.

https://doi.org/10.26650/jos.826438

\section{ÖZ}

XX. yüzyılın başlarında dış güçlerin Kore'yi işgal ettiği dönemde gerçekleşen kadının modernleşme süreci hakkındaki araştırmalar, Kore kadınlarının 'vatanperverlik' ve 'milli şuur' altında modern bir bilince sahip olmalarını sağlamakla birlikte bu sürecin Kore bağımsızlık hareketinin tarihi ile kesiştiğini göstermektedir. Kore toplumunun modernleşme sürecinde çelişkili sistemin değişimini öne sürerken aynı zaman zarfında Koreli kadınlar, milletin bu buhranlı döneminde kurdukları çeşitli vatansever dernekler ve eğitim faaliyetleri aracılığıyla ülkeyi yabancı güçlerden kurtararak yeniden doğması için her türlü fedakârlığı yapmıştır. Böylece kadınlar, eğitim hayatında ve aydınlanma sürecinde erkeklerle birlikte ülkenin kaderini belirlemede etkin rol almalarının gerektiği çağrısında bulunurken vatanı kurtarma çalışmalarının bir vatandaşlık görevi olduğunun farkına varmışlardır. Ayrıca Batı'dan gelen modern fikirlerin Kore'ye girmesiyle, kadınlar erkek merkezli Konfüçyüsçü normların var olan tek yaşam tarzı olmadığı bilinci ile kadınların da eşit insanlar ve bireysel varlıklar olduğu düşüncesinin altyapısı hazırlanmıştır. Bu tarihte Kore kadınlarının milli mücadeleye aktif katılımı ve parçası oldukları sosyal hareketler, muhafazakâr geleneğin hâkim olduğu Kore toplumunu şaşkına uğratmıştır. Kore kadınlarının işgal güçlerine karşı ulusal egemenliği geri alma konusu ile bağımsızlık hareketinde erkekler ile yan yana mücadele ettikleri dönem, çağdaşlaşma düşüncesine bağlı olarak sistemleşme süreci olarak ifade edilebilir. Bu süreç aynı zamanda, istiklale kavuşulduğunda kurulacak olan devlet şekli konusunda bir arayış olup Kore'nin cumhuriyet olarak yeniden doğmasında önemli bir rol oynamıştır. Bu düşünce temeli üzerinde, bu araştırmada tarihte kadınların Japon emperyalizmine karşı koyarak ulusal gücü nasıl yeniden tesis etmeye çalıştıkları, Kore kadınları tarafından kurulan milli örgütler ile kişiler aracılığıyla incelenecektir. Anahtar kelimeler: Kore Kadını, Vatanperverlik, Milli Şuur, Kore Milliyetçiliği, Modernleşme

\section{ABSTRACT}

The beginning of the 20th century, which was a period marked by an imperialistic invasion of Korea by external forces, saw the establishment of a modern consciousness in Korean women because of the rise in "patriotism" and the development of a "national consciousness" against the external forces. At the 
same time that Korean women were seeking change to the contradictory modernization of Korean society through their various patriotic associations and educational activities, they were also making many sacrifices to save the country from the external powers during this dark period. Realizing that working to save their homeland was a civic duty, along with the men, the women took an active role in determining the fate of the country while continuing to develop education and promote enlightenment. The introduction of modern ideas from the West brought the knowledge that women were equal and that the male-centered Confucian norms were not the only way of life open to them. Therefore, during the the Korean Independence Movement, women were also developing a modern consciousness as part of their nation building efforts. Despite living in a feudal male dominant social structure ruled by tradition, religion, and conservative thinking, female power was being recognized through the Korean women's achievements against the foreign intervention. Through an examination of Korean women's actions and roles in restoring domestic sovereignty and establishing a modern democratic government, this study elucidates the role of Korean women in the Korean independence movement against Japanese imperialism and their involvement in the foundation of the democratic movements that eventually established the Korean republic.

Keywords: Korean Women, Patriotism, National Conscience, Korean Nationalism, Modernization

\section{EXTENDED ABSTRACT}

The modern idea of women's rights emerged in Korea in the 18th century. By participating in the independence struggle after Japan invaded Korea, Korean women patriotically protected national sovereignty. The national struggle by Korean women was a unifying movement that helped rebuild modern Korea. While the women's movements in the rest of the world were somewhat similar to the movement in Korea, because of the chaos associated with the imperialist occupation, there were few historical precedents for the national struggle of Korean women, which was an important feature of Korea's national independence movement and attracted the attention of the international community.

This study examines Korea's modernization in a critical period in its history through the national consciousness struggles of the Korean women to break down the traditions and customs. Besides the opening of many girls' schools by women's organizations, the women also were also involved in various patriotic organizations during this dark period with the aim of establishing a country based on equality and freedom.

Despite the traditional male-centered society, while working to gain their own freedom, Korean women also played an active role in regaining Korea's freedom from oppression. Alongside the men, Korean women stood up to Japanese bullying and played significant roles in the national patriotic movement to develop a gender equal consciousness. Therefore, this study emphasizes the role Korean women played in the establishment and rebirth of the Korean republic, their success in liberating the country from foreign powers, and the sacrifices they made to revive the country's economy.

Specifically, by examining the patriotic activities of the women before the March 1 National Movement, which best demonstrated the will of the Korean nation for independence, the role of Korean women in the modern enlightenment national movement and how they caused a revival in the national consciousness is revealed. Besides supporting the national independence 
movement, after the March 1 Movement, Korean women also contributed to issues such as education and economic development. However, even today, the traditional Korean notion of society and its patriarchal understanding of history have tended to identify women as only members of the nation, with the historical importance of their role in society during the occupation somewhat underestimated. As there have been few studies on the actions of Korean women during Japanese colonial rule, there is a great need for further research.

Therefore, with a focus on the changes and developments in the women's movement in early 20th century contemporary Korean history, the activities associated with Korean women's enlightenment and their roles in the national movement are evaluated to reveal their historical significance in the re-establishment of national sovereignty. To achieve this goal, previous research on the activities of the people involved in the women's national movements in Korea and the activities of the organizations, and reports in the newspapers published in that period are used as references.

In the end, Korea's modern women's movement also assumed a bigger role within the nationalist movement. In Korea, women were an integral part of the independence movement against foreign powers and stood as equals with the men by participating in the armed uprisings, establishing patriotic organizations, and undertaking resistance efforts, all of which eventually led to the foundation of a democratic government. 


\section{Giriş}

Tarih boyunca aynı bölgede diğer ırklarla ilişki kurmadan kendi başlarına yaşamış olan Koreliler, Anthony Smith'in ortaya atmış olduğu 'ethnie'1 özelliğine her daim sahip olmuşlardır. Ancak XX. yüzyılın başında Kore milleti milli egemenliğinin sarsıldığ 1 kritik bir döneme girmiştir. Kendisini hanedan ile krala bağlı "halk" yerine çağdaş devletler hukuku ve eşitlik düşüncesiyle modern anlamda "millet" olarak algılamaya başlamıştır. Kore milleti kavramı Smith'in deyimiyle, ortak mitlere, tarihsel anılara, kitlesel bir kamu kültürüne, ortak ekonomiye ve tüm üyeleri için geçerli, belirli bir isme sahip aynı toprağı paylaşan insan topluluğuna karşılık gelmektedir.

Kore eski adıyla Joseon², gerek jeopolitik konumu, gerek zengin yer üstü ve yer altı kaynaklarıyla dünya güç merkezleri için mutlak kontrol edilmesi ve elde bulundurulması gereken bir hedef haline gelmiştir. Diğer yandan kendi kendine yeterlilik prensibini ve dışa kapalı bir siyaseti kabul eden Joseon Hanedanlığı, tarihte uzun zaman boyunca dış dünyanın diplomasi yöntemleri ve politikalarına hem ilgi göstermemiş hem de onları doğru olarak öğrenememiştir. Böylece, yeniçağın başlarında dünya, özellikle Avrupa'nın rönesans ve reform hareketleriyle bir değişim ve gelişim süreci yaşarken, Joseon'un önceki yerini bile koruyamaması devletin gerilemesinde ve çöküşünde etkili olmuştur.

Devletin gerilemesinin en önemli nedenlerinden biri de Joseon'un eğitim alanında ilerici hamleler yapamamış olmasıdır. Joseon Hanedanlığı pozitif bilimler yerine Konfüçyüs bilimlerine öncelik tanıyarak toplumun hiçbir alanda modernleşme ihtiyacını karşılayamamıştır. Eğitim alanında ihtisaslaşmanın ortadan kalkmasıyla beraber, yükseköğretimin altındaki eğitim kurumunun geniş kitlelerin faydalanabileceği bir şekilde yaygınlaştırılamaması toplumdaki eğitimin dar bir çerçevede kalmasına sebep olmuştur. Ayrıca "Neo-Konfüçyüsçülük"( 성리학) ${ }^{3}$, Joseon'da mevcut bulunan toplumsal yapının ve sınıfsal düzenin şekillenmesinde önemli bir değişiklik yaratırken, yeni bürokrat sınıfı olan akademik "Yangban"(양반) ${ }^{4}$ sınıfı tarafından ideolojik bir temel olarak kabul edilmiştir. Joseon Hanedanlığı’’nın yönetim sistemi olan Neo-

1 Smith'e göre, milletin kim olduğu sorusunun yanıtı milletlerin etnik temellerinde aranmalıdır. Çünkü günümüz milletlerinin çoğu belirli bir etnik topluluğun devamıdır. Herhangi bir etnik topluluğun altı temel özelliği vardır: Kolektif bir isim, bir ortak soy miti, paylaşılan tarihsel anılar, ortak kültürün ayırt edici bir veya birkaç öğesi, belirli bir "anavatana" duyulan bağ, topluluğun önemli bir bölümü için geçerli olan bir dayanışma duygusu. Smith, etnik topluluk yerine Fransızca'dan ithal ettiği "etnie" terimini kullanmıştır. Smith, D. Anthony. The Ethnic Origin of Nations, New York: Basil Blackwell Ltd, 1986, s. 275

2 Joseon: 1392-1897 yılları arasında var olmuş bir hanedanlıktır. Kore'nin eski adıdır.

3 Joseon döneminde Konfüçyüsçülük ortodoks devlet dini haline gelirken XIV. yüzyılın başlarında Yu An adlı kişi Neo-Konfüçyüsçü öğretiyi Çin'den öğrenip getirmiştir. Yüksek düzeyde kurumsal, öğretisel olan bu felsefe, insan doğası ve kralın otoritesiyle ilgilenerek evrendeki düzeni fizik ötesi kurallarla açıklamaya çalışmıştır. NeoKonfüçyüsçü görüşün siyasal anlayışına göre halk kralın otoritesine boyun eğmeli ve ona mutlak bir bağl1lık göstermek zorundadır. Cha, Sung-hwan, Kore Din İdeolojisinin Sosyal Anlaylşl (한국종교사상의 사회학적 이해), Seul: Munhakkwa Jisungsa, 1995, s. 100.

4 Yangban(양반): Joseon döneminde kullanılmaya başlanan Yangban kelimesi, Çince'de çift anlamına gelen "Yang"dan türemiş̧tir. Aslında yangban, sivil memur olan Doğu makam (동 반 Dongban) ve askeri memur olan Batı makam (서반 Seoban) olarak, iki kısımdan oluşmuştur. 
Konfüçyüsçülük felsefesinden siyasi güç kazanarak yükselen Yangban sınıfı, ekonomik, siyasi ve sosyal ayrıcalıklara sahip olmuştur. Bu makam, doğrudan bütün aile mensuplarının sosyal konumunu da etkilemiştir. Yangban olan kişinin ailesi de devlet yönetiminde elit kesim olarak çeşitli toplumsal imkan ve ayrıcalıklardan yararlanmıştır.

Joseon Hanedanlığı'nın son zamanlarında, sınıfsal sistemin alt tabakasına ait olan kadınların hakları daha da kısıtlanmıştır. Toplumda kadınlara sessiz, uyumlu, sadık ve namuslu olmaları, yaşantısındaki en yüce amaç ve erdemin "bilge bir anne ve iyi bir eş" olması, evlat olarak babaya, eş olarak kocaya, bir dul olarak da ilk oğluna bağlı olması bir kadının hayatını yöneten temel kurallar olmuştur. Toplumun bu ortamı içinde kadınlar, konumlarının gittikçe gerilemesiyle önceden sahip oldukları mülkiyet haklarını bile yitirmiştir. ${ }^{5}$ Ayrıca toplumsal yasalara göre kadınlar, dışarı çıktıklarında yüzlerini ve başlarını başörtüleriyle kapatmak zorundaydı.

$\mathrm{Bu}$ dönemde, Kore kadınlarının konumunun gelenek ve görenek kalıbı içinde sınırlandırılması kadının toplumsal vaziyetinin ve ortamının önemli ölçüde Konfüçyüs öğretisi ve kavramlarının etkisi altında olduğunu gösterir. Konfüçyüs'ün toplumsal kurumsallaşma olgusu benimsenirken, onun insan ilişkilerini yöneten şu beş ilkesi önemsenir: "Halkın kendisini yönetene salt bağlllı̆̆l olması, çocukların ebeveyne boyun eğmesi ve saygllı olması, karl-koca arasında gerçek sevgi ve saygı olması, yaşı küçük olanın yaşça büyük olana saygılı olması, arkadaşlar arasında kuşkuya yer olmayan güvenin olması." 6

\section{Joseon'un Son Döneminin Toplumsal Durumu ve Düşünce Hareketi}

Kore tarihinde Joseon Hanedanlığı'nın son zamanları hakkında şimdiye kadar çoğu tarihçi o dönemde yaşanan olayları Batı'dan ithal edilen modernist yaklaşımla açıklamaya çalışmıştır. ${ }^{7}$ Fakat Batılı "modernist yaklaşımın” Joseon'un son dönemlerini doğru ve tarafsız bir biçimde yansıtmasının mümkün olup olmadığının, bu doğrultuda söz konusu yöntemin tarihsel yorumunun veya analizinin Kore'de çok tartışıldığ 1 görülmektedir. Bu konuları iyice anlamak için o döneme ait olayları bir bütün olarak incelemek gerekmektedir. Çünkü Kore'deki tarih incelemeleri arasında bu dönemin olaylarına yönelik yorumlar yeterince net biçimde yer almamaktadır. XVII. yüzyılın ortasından XX. yüzyıla kadar, yaklaşık 250 yılı bulan dönem hakkında tarihçilerin yaptığı yorumların ikiye ayrıldı̆̆ı görülmektedir. Bir tarafta, tarihsel esnekliğini kaybeden Joseon Hanedanlığı'nın dağılış zamanı olarak görenler varken diğer tarafta aynı devri, Yangban sınıfının yanı sıra sıradan insanların geliştirdiği halk kültürü ile vatandaşların kültürel yaşamlarını zenginleştiren Kore kültürünün “altın çağı” olarak niteleyenler de vardır.

5 Ahn, Min-jung, “Joseon Döneminde Kadının Ahlâki Eğitimi Araştırması”(조선시대 여성윤리 교육 연구), Yüksek Lisans Tezi, Busan Üniversitesi Eğitim Fakültesi Etik Eğitimi Bilim Dalı, Busan, 2008. s. 28.

6 Cha, a.g.e., s. 79-80.

7 Lee, Mee-lim, “Wijeongcheoksa Düşüncesi ve Modern Milliyetçiliği: Hwaseo Lee Hang Lo'nun Milliyetçilik Anlayışı İncelemesi” (위정척사 사상과 근대 민족주의: 화서 이항로의 민족의식에 관한 연구), Seul: Kore Felsefesi Araştırma Yay, 1999, Kore Cheolhak Nonjip, Vol.11, s. 30. 
Joseon Hanedanlığı'nın son dönemlerinde siyasi düzen, toprak kanunu reformu ve sınıf ayrımını ortadan kaldırma reformu gibi Kore halkının çözmesi gereken sorunların başında milli muhafaza sorunu bulunmaktaydı. XIX. yüzyılın ortalarında başlayan Kore anavatanına yönelik dış güçlerin silah gücüyle ele geçirme çabaları ve ekonomik müdahaleler, sosyal ve kültürel istilaya yol açarken nihayetinde ulusal ruhun yok edilmesini amaçlamıştır. Kore halkı varoluş kriziyle karşı karşıya kaldığında, Kore'nin entelektüelleri ve politikacıları "Dışa Kapalılık" düşüncesi ve "Batı ile Japon medeniyetini ve gücünü reddetme" ilkesini temel alarak yabancı devletlerle münasebetler kurulmasına karşı çıkmıştır. Bu düşünce akımı daha sonra ideolojik sınırları aşarak güçlü ülkelerin istilasından ülke ve ulusu korumak için 'Wijeongcheoksa' (위정척사) ${ }^{8}$ fikir hareketine dönüşmüştür. Joseon tarihinin en zor ve kritik zamanlarında ortaya çıkan bu fikir hareketi, Konfüçyüsçü öğretiyle beslenen Kore geleneksel milli şuuruna dayanmaktadır. Wijeongcheoksa hareketi, zamanla büyük bir bağımsızlık düşünce akımı oluşturarak vatansever gönüllü ordu teşkilatının ana dayanağı haline gelmiştir. Bu sebeple Joseon'un son döneminde ortaya çıkan Wijeongcheoksa düşüncesinin, sadece Konfüçyüs öğretisi düzeyinde kalmayıp Kore milletine istiklal şuurunu aşılayan bir milli harekete dönüştüğü söylenebilmektedir. Çünkü Joseon Hanedanlığı’nın güçlü devletler karşısında çaresiz kaldığı son dönemlerinde, milli kimliği kuvvetlendirmek amacıyla çok sayıda aydın Wijeongcheoksa düşüncesine destek vermiştir.

Dışa Kapalılık politikasını destekleyen Wijeongcheoksa'nın, her ne kadar Kore'nin çağdaşlaşmasını geciktiren bir faktör olduğu düşünülse de, diğer yönüyle değerlendirildiğinde milli bilinci uyandırması ve geliştirmesi yönüyle büyük bir öneme sahip olduğunu söylemek mümkündür. Joseon halkının batılı devletler ve Japonya'nın istilacı gücünün farkına vardıktan sonra bu tehdide sadece devletin karşı koymasını beklemeden direniş hareketi oluşturacak şekilde örgütlenmesi, Kore'nin modern milli tarihinde küçümsenmeyecek öneme sahip bir gelişme olarak değerlendirilmektedir. Bu doğrultuda Japonya başta olmak üzere Kore Yarımadası'na gelen dış güçlere karşı ortaya çıkan Korelilerin düşünce hareketinin, direnç ve münhasır özelliklerine sahip olduğunu söylemek mümkündür.

XX. yüzyıla gelindiğinde 1904 yılında Kore'nin imtiyazı için gerçekleşen Rusya -Japonya savaşında galip gelen Japonya, Kore'yi işgal etmiş ve 1905 yılında Eulsa Antlaşması'nı zorla akdettirmiştir.9 Japonya bu antlaşmayla Joseon'un toprak bütünlüğünü ve diplomatik ilişkilerini gözetme hakkını himayesi altına aldığını ilan etmiştir. Bununla ilgili haberler Koreliler arasında yayıldıkça halkın öfkesi artmıştır. Milliyetçilik düşüncesini savunan Hwangseong Gazetesi(

8 Joseon'un son zamanlarında "milli kimliği ve milli kültürü savunmak” şeklinde ortaya çıkan Wijeongcheoksa fikir hareketi, Çince' de “doğru olanı savunup yanlış olanı reddetmek” anlamına gelmektedir. Joseon Hanedanlığı'nda bu ideolojiyi savunanlar Wijeongcheoksa olarak adlandırılmıştır. Jeong, Eun Kyung, Kore Milliyetçiliği-Kore'de ve Türkiye'de Milliyetçilik Anlayışlarının Gelişme Süreçleri (1910-1945), İstanbul: Likya Yayınları, 2016, s. 51

9 Rus-Japon Savaşı'ndan galip çıkan Japonya, 5 Eylül 1905 Portsmouth barış hükümleriyle Joseon'daki nüfuzunu daha da güçlendirdi. Aynı yılın Kasım ayında Joseon Kralı Kojong'a bir himaye anlaşması zorla kabul ettirilmiştir. Kore takviminde bu yıl Eul-sa(을사) olarak adlandırılmaktadır. Bundan dolayı bu antlaşma, "Eul-sa Anlaşması"( 을사조약) adıyla anılmaktadır. Koreliler bu anlaşmayı "Eul-sa Utanç Anlaşması" (을사늑약)olarak nitelendirmiştir. 
황성신문)'nin müdürü Ji Yeon Jang (장지연 1864-1921), 18 Kasım'da Japonların istilasını ciddi şekilde eleştiren "Siilya Bangseong Daegok” (시 일야방성 대곡Gece gündüz durmadan yüksek sesle ağlamak) başlıklı köşe yazısını yazınca Gazete, bu yazı nedeniyle kapatılmış ve Jang, Japonya tarafından hapsedilmiştir. ${ }^{10}$ Bu olaylar sonucunda, özellikle Seul halkı arasında basın özgürlügüünün engellenmemesi için doğrudan Joseon Kralı'na sunmak üzere Japonya’ya tepki içerikli dilekçe eylemleri başlamıştır.

Ardından on üç vilayetin valilerinden de Kral'a sert bir dil içeren dilekçeler yağmaya başlamış ve bazı valiler sunduğu dilekçe nedeniyle Japon polisleri tarafından ele geçirilip hapsedilince Young Hwan Min (민 영 환1861-1905) adlı Kral'ın muhafiz müdürü bu hareketi devam ettirmiştir. Fakat dilekçe eylemleri belli bir sonuca varamayınca, Min ve diğer bürokratlar devlete karşı olan sadakatlerini göstermek için intihar etmiştir. Ayrıca çok sayıda bürokrat da derin üzüntülerini dile getirdikleri vasiyetnamelerini Kral'a sunduktan sonra canlarına kıymıştır. Kore'nin İngiltere elçisi Han Ung Lee (이 한응 1874-1905) de İngiltere'nin Kore'deki tepkilerini dikkate almayan umursamama politikasından dolayı intihar etmiştir. Böylece, bürokratlar ve halkın vatanperverlik duygusuyla toplu intiharlara başlaması ve Joseon Kralı'na sunulan tepki içerikli dilekçeler Kore toplumu üzerinde büyük yankı uyandırmıştır. ${ }^{11}$

Böylelikle ülkenin kriz karşısında ulusal bilinci büyük ölçüde uyanınca Wijeongcheoksa ideolojisini geliştiren entelektüel elitler, gönüllü ordular kurarak Japon karşıtı mücadeleler yürütmüştür. Ayrıca ulusal ruhun telkini ve ulusal egemenliği yeniden tesis etmek için eğitim ve kültür hareketi ile vatansever aydınlatma faaliyetlerini kapsamlı bir şekilde geliştirilmişlerdir. Fakat, Koreliler ulusal egemenliği çeşitli yollarla geri almayı denemelerine rağmen Japonya İlhak Anlaşması'nın (한일병합조약) ${ }^{12}$ kabul ettirilmesi ile Joseon'un üzerine tamamen el konulmuştur. Japon komutan, birliklerine sarayı kuşattırıp Kral'ı tümden "teslim olmaya" zorladıktan sonra 22 Ağustos 1910'da Japonya Kore’yi sömürme amacını açıkça ilan ettiği bu Kore-Japon İlhak Anlaşması ile Kore resmen Japonya'nın egemenliğine girmiştir. Bu anlaşmayla başlayıp 15 Ağustos $1945^{\prime}$ 'e kadar süren Japon sömürge yönetiminin hüküm sürdüğü o sıkıntılı yıllarda Joseonluların yaşamı her yönüyle olumsuz etkilenmiştir.

Bu durumda Korelilerin söz konusu bağımsızlık hareketi birleşik milli hareket haline gelmiş ve her yaştan ve meslekten kişiler çeşitli yollarla bir araya gelerek geniş çapta katılım sağlanmaya başlamış, kadınlar da millî egemenliği savunmak amacıyla bu hareketin bir parçası olmuştur. Birbirinden farklı konumlarda olmalarına rağmen bu kişilerin ortak noktaları, hepsinin yayılmacılık karşıtı, milli irade ve mutlak bağımsızlık yanlısı olmalarıydı. Kore bağımsızlık hareketi bu üç temel ilkeden ayrıldığı andan itibaren "bağımsızlık hareketi” olarak

10 http://www.history.go.kr/url.jspID(NIKH.DB-tc_md_1905_11_18_0070)

11 Jeong, a.g.e., s.76

12 Bu anlaşma, Kore'nin eski takvimine göre "Kyungsul”( 경술) yılında gerçekleştiği için Koreliler arasında "Kyungsul Ulusal Utanç Yılı" olarak anılır. 
adlandırılmaktan çıkmıştır. ${ }^{13}$ Bu üç özelliğin bulunmadığı hareketlere, sosyal-demokrasi, liberal burjuvazi, anarşizm gibi Batının siyasi düşünceleri katılmıştır. Böyle çeşitli düşüncelerin doğuşu bağımsızlık hareketinin gücünün bölünmesi değil aksine daha da zenginleşmesi anlamına gelmiştir. Çünkü bu düşünce akımları arasındaki fark, sadece hangisine daha çok ağırlık verdikleri konusu olurken her biri milli egemenlik, özgürlük ve eşitlik gibi ortak değerleri vurgulamıştır. Bu çerçevede Kore'de gelişen bağımsızlık hareketinin bir diğer özelliğinin, modern Batılı düşünce akımlarını alıp bunları sistemleştirme süreci olduğu ifade edilebilmektedir.

\section{Kore'de Kadınların Modernleșme Sürecine Girmesi}

Kore'de kadın hareketi tarihini incelemek için ilk önce XVIII. yüzyılın sonuna doğru ortaya çıkan "Silhak(실학)"14 bilimini değerlendirmek gerekmektedir. Çünkü Kore kadın hareketi bu düşünce akımından doğan çağdaşlaşma anlayışından etkilenerek başlamıştır. Silhak bilim akımı, pek çok alanda akademik ilgilerin gelişmesine katkıda bulunduğu gibi çeşitli yeni düşünceler geliştirilip hızlandırılmasında da etkin rol oynamıştır. Bu fikre sahip olan devlet adamları toplumsal ve ekonomik sorunların çözümü için yeni yöntemlerin bulunması ve geleneklerin köstekleyici etkisinden kurtulup uzaklaşmayı savunurken bir yandan tarım ve sanayide yenileşme ve toprak dağılımında köklü reformlar önermiş, diğer yandan toplumu güçlendirmek üzere diğer ülkelerle ticari ilişkilerin geliştirilmesi gerektiğini savunmuştur. Ayrıca Silhak teorisini ortaya çıkaran ve geliştiren Yakyong Jung (정 약용 1763-1836) ${ }^{15}$ adındaki siyasetçi ülkenin olumlu yönde değişmesi için yeni kültürel reformların yapılması gerektiğini vurgularken, kendi yazdı̆̆ 1 "Dogang Gogabusa (도강고가부사Dogang Mahallesi'ndeki Bir Gelin Hikayesi)" kitabında baskı altında kalan kadınların gerçekliklerini kadınların gözünden anlatarak Joseon toplumunun kadınlara yönelik baskısını eleştirmiştir. ${ }^{16}$

Bununla beraber Joseon Hanedanlığı’’nın yönetim ideolojisi olan Neo-Konfüçyüsçü öğretinin Çin ile bağlantılı olması sakıncalı bulunmuş ve yerine yeni bir öğreti araştırılmaya başlanmış, bu arayış sürecinde Katolik öğretisiyle de tanışılmıştır. ${ }^{17}$ Ülkeye "Batı Bilimi” olarak girmiş olan Katolikliğin, XVIII.yüzyılın sonlarına doğru takipçi sayısı giderek artarken bu yeni öğretiye toplumun her sınıfından bir çok kadın da katılmıştır. ${ }^{18}$ Katolikliğin gelişmesi ile kadın-erkek eşitliği ve kadın haklarının benimsenmeye başlamasına rağmen hükümet ve tutucu Konfüçyüsçü siyasetçiler tarafından bu dine yönelik baskı şiddetlenince ${ }^{19}$ kadınlar da susmak zorunda kalmıştır.

13 Park, Chan-Sung, Milliyetçilik Çă̆l-Japon Egemenliği Altındaki Kore Milliyetçiliği(민족주의의 시대-일제하의 한국 민족주의), Seul: Kyungin Kültür Yay, 2007, s. 1

14 Silhak(실학): Uygulamalı Bilimler veya Pratik Bilgiler anlamına gelmektedir.

15 Silhak Bilim akımını temsil eden siyasetçi, yazar ve bilim adamıdır. Lakabı ise Dasan'dır.

16 Lee, Nan-su, "Dasan, kadın gözünden kadını çizdi” (다산, 여성의 눈으로 여성을 그리다), Konfüçüsçülük Düşünce Kültür Araştırması, no. 53, Seul: Konfüçyüs Enstitüsü, 2013, s.171

17 Yoo, Hyung-won, Kore'nin Silhak Düşüncesi, Seul: Samsung Yay, 1989, s. 16.

18 Bu sayı, 1850’lerde 200.000’lere ulaşmıştır. Andrew C. Nahm, Kore Tarihi ve Kültürü, çev. Ali Rıza Balaman, İzmir: E.Ü. Basımevi,1998, s.101

19 Nahm, a.g.e, s. 101 
Katolikliğe yönelik hükümetin kovuşturması devam ederken Batı dinlerine tepki olarak 1860 yılında "Donghak(동학)" ${ }^{20}$ düşüncesi milli bir din niteliğinde başladıktan sonra güçlü bir siyasal ideoloji karakterini taşıyarak gelişmiştir. Toplumsal yenilenmeyi ve insan eşitliğini savunarak ortaya çıkan "Donghak," sözcük olarak "Doğu bilim” anlamına gelmektedir. ${ }^{21}$ Donghak düşünce akımının lideri Je-u Choi (최제우1824-1864), öncelikle bu öğretinin hedefini "ülkeyi korumak ve millî refahı sağlamak" olarak belirledikten sonra toplumdaki sınıfsal sistemi reddetmiş ve eşitliği ön plana çıkartmıştır. Donghak teorisinin temelini oluşturan "Cheonin İlchi” (천인일치 gök ve insan aynıdır) düşüncesini slogan olarak vurgulayarak tüm insanların eşit olduğunu belirtirken, "İnnecheon” (인 내천 Tanrı tüm insanların içinde olduğu için bütün insanlar eşittir) düşüncesini de başlıca önemli ilke olarak kabul edip cinsiyet eşitliğini savunarak halka duyurmuştur.

Buna ilaveten Donghak, insancıllık ve eşitlik fikirlerini temel aldığı gibi feodal sistem ve yayılmacılık karşıtı bir duruş sergilediği için halk arasında pek çok yandaş kazanmaya başlamıştır. ${ }^{22}$ Donghak öğretisinin, kadınların sosyal hareketinde eşitliğin ve uygarlaşmanın gerekliliğini ileri sürerek Joseon'un son döneminde cinsiyet eşitliği bilinci ve modern kadın hakları ideolojisini destekleyen tarihsel bir altyapıyı oluşturduğu anlaşılmaktadır. Dolayısıyla "Donghak" in eşitlik düşüncesi, Kore çağdaş tarihinde kadınları aydınlatmada önemli bir rol oynamıştır.

Kore toplumunun modernleşme sürecinde çelişkili sistemin değişimini öne sürerken başlayan çağdaş kadın hareketleri, dış güçlerin istilası altında, çetin koşullar içinde büyüyüp gelişmiştir. Böylece kadınlar, eğitim hayatında ve aydınlanma sürecinde erkeklerle birlikte, ülkenin kaderini belirlemede etkin rol almaları gerektiği çağrısında bulunurken vatanı kurtarma çalışmalarının bir vatandaşlık görevi olduğunun farkına vararak bunu geliştirmişlerdir. Ayrıca Hristiyanlığın Kore'ye girmesiyle kadınlar yeni Batı fikirleri ile tanışmış ve modern eğitimin temelleri atılmıştır. Hristiyan inancıyla gelen Batı kültürü aracılığıyla, erkek merkezli Konfüçyüsçü normların var olan tek yaşam tarzı olmadığı bilinci ile kadınların da erkekler ile eşit insanlar ve bireysel varlıklar olduğu bilincinin altıyapısı hazırlanmıştır.

\subsection{Mart Bağımsızlık Hareket (3.1독립운동) ${ }^{23}$ ve Kore Kadınının Çağdaşlaşma Hareketi}

Daha önce üzerinde durulmuş olan Silhak, Wijeongcheoksa ve Donghak hareketleri olarak bilinen düşünce akımları, Joseon Hanedanlığı'nın dağılmasını önleme ve modern süreç bağlamında ortaya çıkmış hem düşünsel hem de fiili olarak devleti aydınlatma ve kurtarma hareketleri olarak nitelendirilmektedir.

201860 yılında başlatılan Kore'nin modern dinidir. "Donghak," sözcük olarak "Doğu bilimi”" anlamına gelmektedir. Donghak o dönemde Joseon' da yayılan Batı dinlerine tepki olarak milli bir din niteliğinde başlamıştır.

21 Lee, Se-gwon, Donghak Düşüncesi(동학사상), Seul, Nılhanıl Yay, 2002, s. 3.

22 Bu doğrultuda, Donghak hareketi modern Kore tarihinde hem "siyasal" hem de "toplumsal" açıdan toplum düzeyinde bir milliyetçilik hareketi olarak nitelendirilmektedir

231919 yılı Kore takvimine göre “Gimi yılı”(기미년) olduğundan, bu hareket "Gimi Bağımsızlık Hareketi” ( 기미독립운동) olarak da adlandırılmaktadır. 
Ayrıca bu düşünce akımlarından etkilenen kadın hareketi, Kore toplumunun aydınlanma hareketinin bir parçası olarak başladıktan sonra Japonya'nın emperyalist istilası altında yönü milli kurtuluş hareketi olarak şekillenmiştir. Diğer bir deyişle ana vatan başka bir ülke tarafindan ele geçirildikten sonra Kore kadın hareketi, ulusal özgürlüğü ve egemenliği yeniden kurma arzusu ile öne çıkarak ulusal bir harekete dönüşmüştür. Dolayısıyla Koreli kadınların modern bilince sahip olmaları için en önemli tarihsel faktörün dış güçlere karşı ulusal hareket olduğu inkar edilemez bir gerçektir.

$\mathrm{Bu}$ anlayışı temel alarak öncelikle XIX. yüzyılın sonlarında ve XX. yüzyılın başında Kore kadınlarının aydınlanma dönemi ve ulusal hareketinin gelişimini değerlendirebilmek için Kore milletinin bağımsızlık iradesini en iyi şekilde gösteren 1 Mart Bağımsızlık Hareketi'ni incelemek gerekmektedir. "1 Mart Ulusal Bağımsızlık Hareketi” adıyla, 1 Mart 1919 tarihinde tüm ulusun katıldığı büyük bir kitlenin başkaldırı hareketi kastedilmektedir. Bu tarihte Japon sömürge yönetimi egemenliği altındaki Kore milleti, bağımsızlığını ve özgürlüğünü elde etmek için yurt içinde ve dışında topyekûn bir ihtilâl hareketi başlatmıştır. Bu hareket Kore kadınları arasında bağımsızlık konusundaki milli şuurun yeniden canlanmasına yol açarken Kore kadınının bundan sonra sürdüreceği bağımsızlık hareketine manevi bir dayanak oluşturmuştur. Bu hareketin, Kore kadın tarihindeki en önemli anlamı ise, toplumun her kesiminden kadının katıldığı ulusal direniş hareketi olması ve Koreli kadınlara çok güçlü bir ulusal kimlik ve vatanseverlik duygusunu kazandırmasıdır.

\subsubsection{Mart Hareketi Öncesi Kadınların Çağdaşlaşma Hareketi: İlk Modern Kadınların Örgütü 'Chanyanghwe'}

Temmuz 1896' da Korelilerin kendi gücüyle bağımsızlığına kavuşması için Islahatçılar aracılığıyla kurulan Doklip Hyuphwe Derneği (독립협 회) ${ }^{24}$ ve Doklip Gazetesi (독립신문), Kore toplumunun çağdaşlaşma için gerekli ideolojik temelini oluşturmuştur. Özellikle bu yapılar, kadınların toplumsal konumu ve eğitimi gibi çağdaşlaşma hareketleriyle yakından ilgilenmiştir. Doklip Gazetesi, yayınlanmaya başlamasından itibaren dokuz ay içerisinde dört defa kadınların meselelerini kaleme almıştır. Gazetede kadınların da eğitim görme ihtiyacının olduğunu önererek toplumsal olarak kadınların eğitim hakkı konusunu kamuoyuna olumlu bir şekilde yansıtmaya çalışmıştır. Islahatçıların toplumsal uygarlaşma hareketleriyle gerçekleşen radikal değişim süreci içinde az da olsa kadınlara, çağdaş eğitim görme firsatı tanınmıştır. Bu akımı destekleyen Doklip Gazetesi'nin katkısıyla 1898 yılında Kore'nin ilk modern kadın örgütü olan 'Chanyanghwe'(찬양회) kurulmuştur. ${ }^{25}$

Chanyanghwe'nin, kadınların da halkın bir üyesi olup erkeklerle eşit şekilde eğitim alarak vatanseverlik fırsatına sahip olması, ekonomik bağımsızlıklarının sağlanması bağlamında kadın okulu kurma hareketi ve kadın aydınlanma projesi ile Kore toplumunda önemli bir

24 Temmuz 1896'da Jae- Pil Seo Seo (서재필 1864-1951) tarafindan bağımsızlığa kavuşmak için kurulan sosyal bir dernektir: Seo, Siyasetçi, Bağımsızlık hareketçisi ve basın mensubu olarak Kore kurtuluş hareketi için çalışmış bir kişidir. Kendisi Ocak 1896'da ABD'den "Kore halkına ders vermek ve yeni bir önder yetiştirmek amacıyla" Kore’ye geri dönmüştür. Kore'ye dönen Seo'nun ilk işi, hükümet ve yurt içindeki 1lımlı sslahatçıların destekleriyle Korece ve İngilizce Doklip Sinmun'u (독립신문 Bağımsızlık Gazetesi) yayınlamak olmuştur. Hemen ardından genç ulusalcılar ve reform yanlılarıyla tekrar bir araya gelerek Bağımsızlık Derneği’ni(독립협 회) kurmuşlardır. Shin,Yong-ha, Doklip Hyeop-hwe Araştrrmasl I (독립협회연구 I), Seul: Iljokak yay, 2006, s. 154. 
tarihsel olay başlattığı görülmektedir. Çünkü bu örgüt tarafından 1898 Eylül ayında kız okulu kurma önergesi yayınlanarak erkek ve kadınların eğitim alanındaki eşitliği vurgulanmış, Ocak 1899 'da kadınların eğitimine ithafen Kore'nin ilk milli kız okulu olan 'Sunseong Kız Okulu'( 순성여학교)nun kurulmasıyla bu sürece öncü olunmuştur. ${ }^{26}$

Chanyanghwe'nin kuruluşu ve faaliyetleri, Kore modernleşme sürecinde kadın eğitiminin gerekliliğinin toplumun tüm kesiminin farkına varmasına katkıda bulunarak kadınlara uygarlaşma ve ulusal göreve erkekler gibi katılma fırsatını sağlamıştır. Ayrıca kadının bağımsız birey olduğunu fark edip eğitim hakkına ve milli kurtarma saflarına kendini adayan ilk kadın örgütü olması bakımından tarihsel öneme sahip olduğu söylenebilir. Chanyanghwe'den sonra, 1905-1910 tarihleri arasında Japonya tarafından devletin düşürüldüğü kritik durumda, özel kuruluşlar, kurtuluşun kadın erkek ayırt etmeksizin milli bilinci geliştirmek olduğu algısına sahip olmuştur. Bu doğrultuda, kızların öğrenim görebilmesi için sivil örgütler aracılığıyla çok sayıda kız okulları açılmıştır. Tüm yurtta kurulan kız okulları hakkında net bir istatistik bilinmemektedir. Fakat Ekim 1908 yılında Seul'de kız okullarına yönelik bir toplantıya katılan dokuz okul (418 kişi) ve buna ek olarak Hristiyan okulları da sayıldığında yalnızca Seul'de yirmiyi aşkın kız okulunun kurulduğu anlaşılmaktadır. ${ }^{27}$

Böylece, Kore toplumunun aydınlanma sürecinin bir parçası olarak başlayan çağdaş kadın eğitim hareketleri, Japonların istilası altında gelenek ve göreneklerin devam ettirilmesinden kaçıp ulusal bilinç ile birlikte gelişen milliyetçi hareket olarak değerlendirilebilmektedir. Kadınlar eğitim hayatında ve aydınlanma sürecinde erkeklerle birlikte ülkenin kaderini belirlemede etkin rol almaları çağrısına olumlu şekilde yanıt vermiştir. Aydınlanma düşüncesi ile birlikte Chanyanghwe kurulduktan sonra kadınların topluma katılma bilinci önceki döneme nazaran daha aktif şekilde değişmiştir. Ayrıca, Japonya’nın Kore'ye yönelik yayılmacı politikasının somutlaştığı bu dönemde kadınlar kendi konumunu geliştirerek erkeklerin yedeği olmak yerine, ulusal egemenliği yeniden tesis eden etkin eylemlerle öznel bir rol oynamaya başlamıştır.

\subsection{Kadınların Devlet Borcu Ödeme Hareketi}

Kore tarihinin bu döneminde kadınların, vatanı kurtarma çalışmalarının bir vatandaşlık görevi ve eşitliği savunmanın önemli bir olgu olduğunun farkına vararak kendilerini geliştirdikleri görülmektedir. Kadınların yürüttükleri vatanseverlik hareketlerinden en önemlisinin 1907'de başlatılan "Devlet Borcu Ödeme Hareketi” (국채보상운동) olduğu söylenebilir. Bu harekete yaş, sosyal sınıf ve bölge fark etmeksizin tüm toplumsal kesimlerden kadınlar hem bireysel

26 Chanyag-Hwe(찬양회); 1900 yılında ekonomik sıkıntı çeken örgütün faaliyetleri, 1903'te Chanyang Hwe'ye öncülük yapan kurucunun ölümüyle durduruldu. Bu nedenle Sunseong Kız Okulu varlığını 1903’e kadar sürdürebilmiştir.

27 Yong Ok Park, "1 Mart Öncesi Kadın Hareketi” (3.1 운동 이전의 여성운동), 1 Mart 50. Y1ldönümü Anma Tezi, , Seul: Don-A Yay,1969, s. 73 
hem de örgütsel katılımlar sağlamıştır. ${ }^{28}$

1905 'te Kore'nin diplomatik haklarını elinden alan Japonya, Kore ekonomisini sömürge düzeni içine almak amacıyla Kore'nin 13 milyon won dış borcu olduğunu iddia etmiştir. Bununla beraber, Kore ekonomisi ve politikasına karışmaya başlayan Japonya, 1905 'te Japon Maliye Uzmanı Megata'yı Kore’ye göndererek Kore bankalarını Japon bankacılık sistemine bağımlı kılmaya çalışmıştır. Giderek Japonya'ya her alanda bağımlı hale gelen Kore'nin borcu ödeme gücü kalmayınca Ocak 1907'de Japonya'ya borcunu ödemek için Daegu'da bazı kişiler kitlesel bir hareket başlatmıştır. ${ }^{29}$

Bununla ilgili, 21 Şubat 1907'de Daehan Günlük Gazetesinde (대한일 보) şöyle bir haber yayınlanmıştır:

"Vatanımızın kaderi 13 milyon wonluk devlet borcunu ödemeye bağll. Artık kendimizi yenileyip vatanımıza karşı vefakârlığımızı göstermenin zamanı geldi. Bu borcu ödersek ülkemiz ekonomik bağımsızlığını elde edecek, ödemezsek ülkemiz Japonya'ya hep bağımlı kalacak ve topraklarımız elden gidecektir. Toprağımızı kaybedersek geri almak mümkün olmayacaktır. Maalesef şimdi devlet bütçesinin bunu ödeyecek yeterli gücü yok. Millet olarak böyle bir duruma kayıtsız kalamayı. 20 milyon nüfusa sahip milletimizin bu parayı toplamak için, üç ay boyunca sigarayı bırakarak kişi başı her ay 20 won toplamasıyla hedefe kolayca ulaşabiliriz. Bu parayı toplayamadiğımız takdirde mutlaka aramızda gönüllü olarak büyük para bağışlayacak kişiler vardır." ${ }^{30}$

Özellikle bu dönemde Devlet Borcu Ödeme Hareketine yol göstermek için kadınlar tarafından ülke çapında otuz tane örgüt kurulmuştur. Kadınlar, sigaradan daha değerli nakite çevrilebilirliği olan altın ve gümüş gibi mücevher ile günlük tahıllar gibi erzaklar biriktirerek Devlet Borcu Ödeme Hareketine katılıp fon yaratma konusunda önemli katkılarda bulunmuştur. Dahası Devlet Borcu Ödeme Hareketi yüksek sınıf, hristiyanlar, tüccarlar ve öğrenciler dahil olmak üzere çeşitli statülere sahip kadınların eşit şekilde katılmasıyla geleneksel kavramları kırarak ulusal bir hareket haline gelmiştir.

Kadınlar, borç ödeme çalışmalarını genelde bir örgüt halinde yürütürken, Pyungyang ve Jinju şehirlerindeki gisaenglerin bu harekete katılmasıyla ${ }^{31}$ cinsiyet veya sınıf ayrımı sınırının aşıldığı net bir şekilde görülmektedir. Bu faaliyetler, eşitliğin temelinde bulunan çağdaş millet anlayışı ile egemenliği geri almak için ayrımcılığı ortadan kaldırarak, kadınların ulusu kurtarma hareketi şeklinde birlik ve beraberlik duyguları içinde hareket ettiklerini de göstermektedir. Ayrıca kadınların gücüne karşı olanların gözündeki değerlerini yükseltmelerine firsat olmuştur.

28 O dönemde yayınlanan Daehan Gazetesi, Hwang Sung Gazetesi, İmparatorluk Gazetelerinin araştırmalarına göre, Taegu, Seul, Pusan, Chwangwon, Ansung ve Chinju gibi şehirlerde yaklaşık 30 tane Devlet Borcu Ödeme örgütü kurulmuştur. Park, Yong-ok, "Devlet Borcu Ödeme Hareketine Kadınların Katılması” (국채보상운동에 의 여성 참여), Sachong, vol: 12, Seul: Koryo Üni. Yay, 1968, s. 65

29 Park, a.g.e., s. 62.

30 Daehan Günlük Gazetesi(대한매일신보), 21 Şubat 1907

31 Pyungyang ve Jinju'deki gisaengler (geyşalar), değerli eşyalarını satıp devlet borcu ödeme çalışmalarına katıldılar. Ayrıca, Kadın Topluluğu'nu örgütleyerek hareketlerini sürdürmüşlerdir. Choi, Sook-ryun ve Jeong, Se-hwa, Uygarliğın Geliştiği Zamanda Kore Kadınlarının Çağdaş Anlayışının Oluşması(문화 발전기와 한국 여성들의 근대화 인식의 형성), Kore Kültür Araştırma Merkezi, Seul, 1976, s.21 
Devlet Borcu Ödeme Hareketinin Japonya'nın baskısı ile başarıya ulaşamamış olmasına rağmen erkek kadın eşitliği temelinde, kadınların ulusal projeleri destekleyerek modern anlamda ulusal bilinç anlayışının farkına varmış oldukları görülmektedir.

\section{Mart Hareketi'nden Sonra Gelişen Kadın Hareketi}

Koreli kadınların milli hareketi, 1 Mart Bağımsızlık Hareketi’nden sonra Japonya'nın o zamana kadar siviller üzerinde yürüttüğü "Silahlı Militarist Politikası" ndan "Uygar Yönetim" sürecine girdiği için yön değiştirmiştir. ${ }^{32} \mathrm{Bu}$ "Uygar Yönetim Politikası" uygulamasının ardından, Korece gazete ve dergilerin yayınlanmasına, sıkı bir denetim altında da olsa izin verilmiştir. Ayrıca dernek kurma özgürlüğü, Kore'deki Japon sömürge egemenliğinin geçerliliğine karşı çıkmamak koşuluyla geniş̧letilirken yeni siyasi koşullar altında kadınlar da milli hareketi daha da aktif şekilde yürütebilmiştir.

\subsection{Shanghai Geçici Hükümetinin Kuruluşu ve Daehan Yurtsever Kadınlar Derneği}

1 Mart Hareketi'nden sonra kadınların aktif katılımı ile Japonya'ya karşı direniş arzularını dile getirdikleri dönemde, Nisan 1919 tarihinde Shanghai Geçici Hükümetinin(상해임시정부) kurulmasıyla birlikte ülke içinde ve dışında birçok grup ile örgüt kapsamlı bir şekilde teşkilatlandırılıp çalışmalara başlamıştır.

Öncelikle Hristiyan kadınlar Geçici Hükümeti destekleyen gruplar oluştururken “On milyon Koreli kadının gücünü birleştirerek bağımsızlık ruhunu ateşlendirip bağımsızlık hareketi için birbiriyle işbirliği içinde olması ve Geçici Hükümete mali destek vermesi" sloganı altında "Daehan Yurtsever Kadınlar Derneği”" (대한애국부인회) kurulmuştur. ${ }^{33}$ Bu dernek, kadınların topladığı fonları Geçici Hükümete göndererek bağımsızlık hareketine destek sağlamaya çalışmıştır. Fakat, Kasım 1919'dan Ekim 1920 yılına kadar Japon polisi tarafından pek çok sayıda üye hapsedilmekle kalmayıp Japonya'nın baskısı nedeniyle faaliyetler belirli bir süre durdurulmak zorunda kalmıştır.

\subsection{Sağcı ve Solcu Kadınların Birleşik Teşkilatı Kunuhwe}

1920 yılının başında ülkeye sosyalizmin girmesiyle 1 Mart Hareketi sonrası milli hareketler, genelde Milliyetçilik ve Sosyalizm hareketi olarak iki büyük akım hâlinde gelişirken ideolojisi, yöntem ve öncü güçlere göre birbirinden ayrılmaktadır. Çünkü milliyetçilik gruplarında da

32 Eylül ayında Saito Makotpo adlı bir emekli amiral Kore Genel Valisi olarak atandıktan sonra, Seul istasyonunda yaptığı konuşmasında "uygar bir kültür” yönetimi izleyeceğini söylemiştir. Kim, Jong Soo, Kore Tarihi Dersi( 한국사 강의), Hanwool yay. Seul: 1989. s. 284

33 Yong Ok Park, Kore Kadınının Japon Karşıtı Hareketi Tarihi Araştırması(한국여성 항일 운동사 연구), Seul: Jisik Saneopsa, 1996, s.251 
sol ve sağ ya da uzlaşma, anti uzlaşma gibi ideolojik farklılıklar oluşmaya başlamıştır. ${ }^{34}$ Fakat milli menfaat için sağcılar ve solcular bir araya gelip Şubat 1927'de Shinganhwe (신간회) isimli milliyetçi derneğini kurmuşlardır. Shinganhwe'nin kurulmasından etkilenen sağcı ve solcu kadın önderler de bir araya gelerek, birleşik bir cephe halinde kadınları temsil edecek "Kunuhwe" (근우회Şaron Gülünün Dostları Derneği) teşkilatını Mayıs 1927 tarihinde kurmuştur. "Kunuhwe", Kore'nin ulusal çiçeği olan "mugunghwa" (şaron gülü) anlamına gelmektedir. Kadın yazarları, öğretmenleri, öğrencileri ve işçileri bir araya getirmeyi hedeflemiştir. Koreli kadınlar arasında ulusal bilinci oluşturmaya çalışan derneğin önderleri, kırsal kesim kadınlarının yanı sıra özellikle fabrika işçilerinin sorunlarını da göz önünde bulundurarak "Genç Hristiyan Kadınlar Derneği” yle (대한여자기독교청년회) birlikte kırsal kesimdeki kadınların da kültürel aydınlanmalarını içeren yeni bir yapılanmayı başlatmıştır.

Milliyetçi ve Sosyalistlerin bir araya gelip kadın hareketi dünyasında bütünleşmelerini sağlayan Kunuhwe; çeşitli sınıflara mensup olan kadınlardan oluşurken, ulus bilinci yükseltip kadın hareketine yön vermiştir. Bu örgütün, sömürge yönetimi altında kadın hareketinin birleştirici gücü şeklinde milli kurtuluş hattından kadın hareketine gelişen bir dönüm noktası olarak tarihte öneminin büyük olduğu söylenebilir.

Böylece eski düşünceye hapsolmuş kadınların aydınlanması için eğitimin mutlaka gerekli olduğu, ulusal ekonominin bağımsızlığı için kadınların rolü konusunda farkındalığın arttırıldığ görülmektedir. Kadınların toplumsal konumuna ilişkin soruların gündeme geldiği dönemde ulusal harekette ortaya çıkan kadınların öznellik ve bağımsızlığı Kore toplumunun karşı karşıya kaldığı feodal sistemde kadınların konumu, ulusun üyelerinin ötesinde kadın erkek eşitliği kavramına dönüşerek aktif olarak sosyal ve politik katılım sağladığını göstermektedir.

\subsection{Joseon Kadın Eğitim Derneği ve Eğitim Faaliyetleri}

1 Mart hareketinden sonra kadın eğitim hareketini yöneten grup olarak 'Joseon Kadın Eğitim Derneği' (조선여자교육회) ilk sırada gelmektedir. 1920 yılında Mirisa Kim’in ${ }^{35}$ (김미리사 1880-1955) öncülüğünde kadınlara bir gece okulu açarak eğitim vermeye başlayan Joseon Kadın Eğitim Derneği’nin amacı, eğitim olanakları olmayan ev hanımlarına eğitim vererek

34 Yayılmacı egemenlik altında kalan Korelilerin siyaset anlayışı, o zamandaki düzene göre uzlaşmacı görüşe yaklaştığı zaman sağcı, uzlaşmadığı zaman ise solcu şeklinde algılanmıştır. Fakat sadece milliyetçilik ve sosyalizm düşünceleriyle karşılaştırıldığı zaman sosyalist (en solcu), milliyetçi (orta) ve Japon yanlıları (en sağcı) olarak algılanmıştır. Park, Chan-sung, Kore Modern Siyaseti düşünce araştırması(한국 근대 정치사상사 연구), Yeoksa Bipyung sa yay. Seul, 1992, s. 80

35 Mirisa Kim (1880-1955): 19 yaşında dul kalan Kim, çağdaş bir öğrenim gördükten sonra, ABD’ye giderek eğitim almıştır. Kore’ye döndükten sonra “Kadının Şiiri” adlı makale dizisini yazmaya başlarken makalenin VI. bölümünde Japonlar tarafından durdurulmuştur. Her zaman Kore kadınlarının aydınlatılması gerektiğini savunan ve bu konuda çalışan Kim, çalıştı̆̆ı Ewha Kız Okulu'nu bırakıp Joseon Kadın Eğitim Derneği'ne kendini tamamen adayarak çalışmalarını arttırmıştır. (Park, a.g.e., s. 252) 
onları bilinçlendirmek olmuştur. ${ }^{36}$ Ayrıca 1921 'de kadın eğitim çalışmalarını Seul dışında da yürütmeye çalışan Kim, yurdun önemli bölgelerinde çeşitli konuşmalar yaparak kadın gece okulları açmaya çalışmıştır. ${ }^{37}$

Bu derneğin kadınların eğitimi konusundaki düşüncesi, toplumun günlük hayattaki talebini karşılayacak şekilde uygulamaya dönük ve gerçekçi olmuş ve giderek kitlesel bir harekete dönüşmesini sağlamıştır. $\mathrm{O}$ dönemin gazetelerinde bu faaliyetler hakkında yürütülen söylev veya konferanslar aracılığıyla durum anlaşılabilmektedir:

1. 22 Mayıs 1920, Hamhung Hristiyan Gençlik (함흥 기독청 년회)salonunda “Toplumsal Gelişme ve Kadın Eğitimi” adlı konferans. ${ }^{38}$

2. 28 May1s 1920, Kesung Dongbu Kilisesi'nde (개성 동부교회) “Koreli ve Yabanc1 Kadınların Karşılaştırılması," "Joseon Kadınlarının Ümidi” adlı kadın konferansı. ${ }^{39}$

3. 30 Mayıs 1920, Pyungnam Sukchun Kilisesi’nde (평남 석천교회) "Yeniden Yapılanma," "İlerici," "Kendine Güvenen," "İmkânsız Yok” adlı seminerler. ${ }^{40}$

4. 19 Haziran 1920, Wonsan Shinchangli Kilisesi'nde (원산 신창리교회) “Günümüzde Yaşayan Bizler Ağlamalı Mıyız Yoksa Gülmeli Miyiz?”, “Zamanı Bilir Misin?” konu başlıkları altında alışkanlıkları ve kadın bağımsızlığını vurgulayan konferans. ${ }^{41}$

5. 1 Temmuz 1920 Andong Kilisesi'ndeki (안동교회) kadın konferansı. ${ }^{42}$

$\mathrm{Bu}$ dönemde kızlara eğitim verme konusunda yabancıların da bir takım çabaları olmuştur. Batılı Hristiyan Grup Birliği, milliyetçilerin üniversite kurma teşebbüsünden ve 1922 Eğitim Kararnamesi'nden faydalanarak üç üniversite kurmayı planlamıştır. Bunların başında Kore'nin ilk kadın üniversitesi olan Ewha Kız Okulu (이화여자학교) gelmektedir. 1886'da bir ABD'li tarafından Koreli kız öğrencileri bilinçlendirmek üzere kurulmuş olan bu okulun, 1910 yılından itibaren dört senelik üniversite bölümünün bulunması sebebiyle Birlik tarafından fakülteleştirilmesi uygun görülmüştür. Bilhassa 1922 yılında Ewha Kız Okulu'nun fakülte kısmında elli öğrenci okuması, Grup Birliği’nin fakülteleştirme çabaları için teşvik edici bir faktör olmuştur. ${ }^{43}$

Dong- $A$ Gazetesi (동아일보), “Kadın Üniversitesinin Gerekliliği” adlı baş makalesiyle Ewha Kız Okulu'nu fakülteleştirmek için okuldaki öğrencilerin ve yöneticilerin çabalarını desteklemiştir. Bu makale şöyledir:

36 Bu olaydan sonra Seul Yumjung Kilisesi'nde başlayan kadınların gece okulu ilk başlarda sadece 13 kişiyken bir hafta sonra 50'yi aşmıştır. Sonraki sömersterde ise 150-160 kadın katılmaya başlamıştır. Gece okuluna katılanların çoğunun Konfüçyüsçülerin eşi olduğu söylenmiş̧tir. (Dong-A Gazetesi 동아일 보, 5 Nisan 1921)

37 Dong-A Gazetesi, 5 Temmuz 1921.

38 Dong-A Gazetesi, 26 May1s 1920.

39 Dong-A Gazetesi, 1 Haziran 1920.

40 Dong-A Gazetesi, 10 Haziran 1920.

41 Dong-A Gazetesi, 25 Haziran 1920.

42 Dong-A Gazetesi, 1 Temmuz 1920.

43 Ewha Kız Okulu'nun anaokul kısmında 100 öğrenci, ortaokul ve lise kısmında 800 öğrenci, üniversite kısmında 50 öğrenci okumuştur. Jeong, Hye Joong, "Metodist Piskoposluk Kadın Derneği ve Ewha Koleji” (미국 북감리교 여성 해외선교부와 이화학당 대학과), Yeosunghak Nonjip., Vol.36 (2), Seul: 2019, s. 26. 
"Kadınların bağımsızlık mücadelesine ve kültür gelişimine olan katkllarl, onların eğitilmeye başlanması ve kızlara eğitim alma firsatının tanınmasıyla gerçekleştirilecektir. Bu, onlar için bir çeşit ışık ve kudret kaynağıdır. Onlara değer vererek onların sahip olduklart yetenekleri geliştirmelerine yardımcı olmalı ve ilkokul, ortaokul ile lise eğitiminden sonra üniversite eğitimi almaları da sağlanmalıdır. Çünkü ortaokul ve lise eğitimiyle kadınlar yeteneklerini geliştirmekte sinırlı kalacaktır. Bu, cahilliği de beraberinde getirecektir. Buna dikkat çekerek kadınlarımıza yükseköğretim görme olanakları da sağlanmalıdır. Bu amacın gerçekleştirilmesi, sadece kadınlar için değil bütün millet için mutluluk ve gelişme kaynă̆ı olacaktır. Bugünlerde misyonerlerle Ewha Kız Okulu yöneticilerinin kızlar ve kadınlar için üniversite kurma planı hakkındaki müjdeyi duyduk. Kadınların bağımsızlı̆̆a kavuşmaları ve kültür gelişimine katkıda bulunmaları için bu üniversiteyi bir an önce kurmalarını candan dileriz. "44

Fakat kamuoyunda Ewha K1z Okulu'nun fakülteye dönüştürülmesinin desteklenmesi, Japon Genel Hükümeti’ni harekete geçirmiştir. Genel Hükümetin Eğitim Müdürlügü, özel okulların fakülteleştirilmesinin kabul edilemeyeceğini açıklayarak Ewha Kız Okulu'nun fakülteleştirilme çalışmasını önlemiştir. ${ }^{45}$

Kadınlar tarafından ortaya çıkan buna çok benzeyen bir diğer eğitim hareketi ise Haziran 1923’te Kore eğitim hareketinin öncülerinden biri olan Me-Rye Sohn (손메례 1885-1963) tarafından başlatılan “Joseon Hristiyan Kadınları Tasarruf Derneği”(조선여자기독교절제회) dir. Bu dernek, içki ve sigarayı bırakarak tutumlu olma gibi günlük hayatı yenilemeye yönelik kampanyayı sürdürmüştür. Bu hareketi başlattıktan üç yıl sonra dernek üye sayısını üç bine çıkarmış ve altmış yerel şubeye sahip olmuştur. ${ }^{46}$ Böylece, 1 Mart Hareketi'nden sonra gelişen kadın hareketi, Hristiyan kadınların öncülüğüyle daha da ilerleyerek milliyetçilik alanındaki faaliyetlerini sürdürmüştür. Kadınların eğitim ve örgüt faaliyetleri aracılığıyla gerçekleştirdiği milli meseleye katılımlar, 1920 yılının başından itibaren toplumun genelinde yaygınlaşarak 1923 yılına kadar varlığını devam ettiren kadın örgütlerinin sayısı 130’u aşmıştır.

Bu dönemde gerçekleşen kadınlara yönelik eğitim çalışmalarının, ulusal egemenliği yeniden tesis etme hedefiyle çağdaşlaşma faaliyetini ve kadınları eğiterek ülkenin rekabet gücünü yükseltmeyi amaçlandığ 1 görülmektedir.

\section{4. Üretim Teşvik Projesi ve Milli Ekonomiyi Geliştirme Çalışmaları}

Bu dönemde yürütülmüş olan, kadınların diğer hareketi ise, Ocak 1923'te milli sermayeyi bağımsız kılmak amacıyla başlayan “Üretimde Teşvik Projesi”(물산장려운동) dir. 1920 yılından itibaren başlayan milletin üretiminde ilerleme çabaları milli sermayeyi ortaya çıkarmış ve kadınların üretime teşvik projesiyle daha da ivme kazanmıştır. Bu durum milliyetçileri daha

44 Dong-A Gazetesi, 25 Şubat 1923

45 Japonya'nın Genel Hükümeti, "Fakülteleştirme Eylemine İlişkin Bir Demeç” adlı başlık altında özel okulların fakülteleştirilmesinin kabul edilmeyeceğini şöyle açıklamıştır. "Joseon' daki yüksekokullar programlarını geliştirip kendi asıl amaçlarına uymaya gayret etmeli. Joseon şartlarına göre yüksekokulların önem kazanmasından dolayı varlığını korumaları tavsiye edilir. Ayrıca yüksek okulların fakülteleştirilmesi görüşümüze aykırıdır. . .” (Dong- $A$ Gazetesi, 16 Temmuz 1923)

46 Lee, Yoon Hee, “Kore Bağımsızlık Hareketi ve Kadınların Rolü”(한국독립운동과 여성의 역할), Kyunghee Sahak, Vol. 21, Seul, 1997, s. 127. 
çok etkileyerek milli ekonomiyi geliştirme çalışmalarını da başlatmıştır. Bu "Üretim Teşvik Projesi”, milli hareketin esas zeminini oluşturan çağdaş bilginler tarafından başlatılırken Kore milletinin yabancı mallar yerine yerli mallar kullanmasının gerekliliğini vurgulayıp bu düşünceyi tüm yurda yaymayı amaçlamıştır.

Bu projenin ana hedefi, yerli mallar kullanıp milli sermayeyi güçlendirerek ekonomiyi canlandırma düşüncesidir. Bu projeyi milliyetçi Man-sik Cho (조만식 1883-1950) şöyle anlatmaktadır:

"Kore milletinin hayatının bu kadar yoksulluk içinde olması, milletin kendisini hor görüp sevmemesindendir. Bu nedenle yabancıların ekonomik istilasina ansızın maruz kallyoruz. Japonların kapitalizminin de etkisiyle üzerimizde, içte ve dışta kurduğu istila tüm yaşantımızı etkilemiştir. Bu istilaya karşı bol bol üretime geçmeli, bunları kullanmalı ve zamanla daha kaliteli hale getirmeliyiz. Böylece milli ekonomiyi bağımsız kılabiliriz. ${ }^{47}$

Aslında bu hareketler erkekler tarafından başlatılmasına rağmen kadınların katılımıyla daha da kuvvetlenmiştir. Kore toplumunun ev hanımları, eski saray görevlileri ve orta sınıf kadınlar, "yaşamak için kendi ekonomimizi iyi idare etmeliyiz" düşüncesiyle milli hareket olarak genişleyen bu projeyi sahiplenmiştir. Bu şekilde Kore kadınının öncü olarak geliştirdiği ulusal egemenliği koruma hareketinin önemi, ulusal hareket konumunda toplumsal ayrımcılık ve önyargı duvarlarını yıkarak, düşünceleri arasındaki farkları aşarak kadınların ortak bir amaç için güçlerini birleştirmesidir. Ayrıca, ülkenin kendi kendine yetebilmesi ve bağımsızlığı için kadın erkek eşitliğini sağlayıp milli bilinç ve vatanseverliği temel alan Kore'nin tamamen bağımsız bir ülke olarak egemenliğini ve gücünü kazanması amaçlanmıştır.

Japonya'nın sömürge yönetimine karşı bir ekonomik direniş hareketi olarak ortaya çıkan Üretim Teşvik Projesi, Kore'nin bağımsızlaşması sürecinde kadınlara, ülkenin milliyetçilik ve cinsiyetçilik kavramlarına ilişkin yeni bir perspektif de kazandırmıştır. Geleneksel feodal yapının içinde her zaman erkeklere bağlı olarak yaşamak zorunda kalan kadınların, bağımsızlık hareketi süresince gösterdikleri aktif ve gönüllü hareketlerin, aniden ortaya çıkışına kadar süre gelen toplumsal eşitliğe ilişkin gösterilen çabanın bir sonucu olarak değerlendirilebilir.

\subsection{Amerika'daki Koreli Kadın Örgütlerinin Ulusal Hareketi}

1 Mart Hareketi'nden sonra Çin, Japonya ve ABD'de yaşayan Koreli kadınlar Korelilerin haklarını savunmak ve egemenliği geri almak için mücadeleyi daha aktif şekilde sürdürmeyi başlatmışken onlar arasında en hareketli olan faaliyet Amerika' da gerçekleşmiştir. Amerika'da yaşayan Koreli kadınların çoğu 1910'dan sonra Amerika'ya göç etmiş fakat 1918 yılına kadar onların faaliyetleri zayıf kalmıştır. O dönemde ABD'de kurulan kadın örgütlerine detaylıca bakılacak olursa, 1908'de kurulan ilk Kore Kadın Derneği(한국여성협 회)'den sonra 1914'te Sekrament Kore Kadınları Derneği, 1917'de Los Angeles’ta Kadınların Dostluk Derneği gibi teşkilatlar kurulmuştur. Onlar genelde Korece eğitimi, kilise faaliyeti, vatandaşlar arasında samimiyeti artırma, ABD'de bulunan Koreli derneklerin merkezi olan Kore Millet Derneği'( 대한국민회)nin desteklenmesi ve Japon mallarını kullanmayı reddetmek gibi etkinliklere

47 Lee, a.g.e., s. 125. 
katkıda bulunmuşlardı. ${ }^{48}$

ABD'deki Koreli kadınlar, 1 Mart Hareketi’nden sonra Kore'nin bağımsızlığını daha etkili şekilde desteklemek için, dağılan kadın örgütlerini birleştirmek amacıyla Daehan Vatansever Kadın Kolordusu'nu kurmuştur. Aynı zamanda Kore Millet Derneği tarafından da onaylanarak ABD'deki Koreli kadınların hareketine yeni bir sayfa açmıştır. Daehan Vatansever Kadın Kolordusu' nun (대한애국여성 단) kuruluş amacı şöyledir:

Vatanın bă̆ımsızlı̆̆ı için Kore Milleti Derneği'yle iş birliği yapacak, evdeki günlük harcamalarından tasarruf edip bağımsızlık hareketine yardım edecek ve vatandaşları bu konuda teşvik edecek, evde Japon malları kullanılmayacak, kadın vatandaşların bağımsızlık düşüncesi geliştirilerek, kadınlar bilinçlendirilecek. ${ }^{49}$

Yukarıda görüldüğü gibi Vatansever Kadın Kolordusu'nun en önemli hedefi bağımsızlık hareketi için fon toplanmasıdır. Bu örgütün, fon toplamak için kullandığı yöntem ise yıllık üyelik parası olarak 3 dolar almak ve ev harcamalarından tasarruf ederek para biriktirmektir. Ayrıca ürettikleri Kore özel sosunu satarak kazandıkları, fon toplarken yapılan tasarruflar ve diğer gelirlerle birlikte 1923 'e kadar toplanan 1.079 doları Shanghai Geçici Hükümeti’ne göndermişlerdir. ${ }^{50}$

Hawai'de ise 15 Mart 1919'da bir takım Koreli kadın, Daehan Kadınlar Yardım Derneği'ni (대한부인구제회) kurarak Kore'deki bağımsızlık hareketine destek olmaya karar vermiştir. Daehan Hanımlar Yardım Derneği'nin birinci hedefi “memleketi için kanını döken, canını feda eden vatandaşlarımızın yakınlarını ve sıkıntı çeken vatandaşlarımızı kurtarmak" ve "bunun için tüm olanakları zorlayarak sonuna kadar mücadeleyi sürdürmek, para toplayıp ebeveyn ve kardeşlerimizi kurtarmak için destek olmaktı" ve bu doğrultuda çağrıda bulunmuştu. Bu şekilde Vatansever Projesi için topladıkları destek paralarını Geçici Hükümet’e ve bağımsızlık ordularına yollamışlardı. Ayrıca, 1 Mart Hareketi'nden sonra, zarar gören milliyetçilerin ailelerine de topladıkları paradan gönderirken bu gruptan Vatansever Projesine toplam 200 bin dolar gönderilmiştir. ${ }^{51} \mathrm{O}$ zaman, ABD'de yaşayan Korelilerin çoğunun, çiftlikte işçi olarak çalıştığı için ayda 35 dolar kazanarak geçim derdi içinde kıt kanaat geçinerek yaşayan insanlar olduğunu varsaydığımız zaman böyle bir durumda toplanan bu paranın gerçekten müthiş bir miktar olduğu anlaşılmaktadır. Ayrıca ABD’de bulunan Koreli kadınlar, II. Dünya Savaşı sırasında Kore'nin bağımsızlık mücadelesinin güçlü ülkelerin kamuoyları tarafından duyulması konusunda da katkıda bulunmuşlardır.

\section{Sonuç}

Kore'de çağdaş kadın hareketlerinin tarihsel anlamını ve gelişme sürecini incelediğimizde bağımsızlık için yapılan faaliyetlerde kadınların da öncülük etmesinin Kore tarihinde kadınlara

48 Park, Yong-ok, “ABD’deki Koreli Kadınların Bağımsızlık Hareketinin Desteklenmesi Hakkında bir Araştırma” (미주한인여성단체의 광복운동 지원 연구), Jindan Hakbo Vol.78, Seul: 1994, s. 274.

49 Park, a.g.e., s. 295.

50 Park, a.g.e., s. 297.

51 Park, a.g.e., s. 299. 
yönelik bakış açısının değişmesini sağladığı anlaşılmaktadır. Bu çalışma aracılığıyla Kore'nin modernleşme sürecinde Koreli kadınların devletin düştüğü kritik durumda gelenek ve görenek duvarını yıkıp nasıl milli bilinç anlayışına sahip çıktıkları tarihsel ortamlarıyla beraber incelenmiştir. Bu doğrultuda, Kore'nin modernleşme sürecinde kadınlara yönelik toplumsal bakış açısının değişimi ve kadınların düşünce gelişimlerine etki sağlayan Silhak, Wijeongcheoksa ve Donghak düşünce hareketleri incelenmiştir. Bu hareketlerin ortak noktası ise Joseon Hanedanlığı'nın modern süreç bağlamında ortaya çıkmış hem düşünsel hem de fiili olarak devleti kurtarmaya yönelik hareketleri olarak nitelendirilmesidir.

Koreli kadınların, milletin bu buhranlı döneminde modernleşme sürecine girerken kurdukları çeşitli vatansever dernekler ve eğitim faaliyetleri aracılığıyla milli, hür ve eşitliğe dayanan ülke kurmak için ne gibi çalışmalar yaptıkları değerlendirilmiştir. Böylece kadınların, cumhuriyet anlayışına sahip ülkenin temellerinin atılması, ülkenin yabancı güçlerden kurtarılması ve yeniden doğması için sağladıkları katkı incelenirken ülke ekonomisinin canlandırılması amacıyla oluşturulan projelerle her türlü fedakârlığı yaparak üstün bir başarı gösterdiği vurgulanmıştır.

Kore kadınlarının modern aydınlanma ulusal hareketinin gelişim sürecini ele almak üzere Kore milletinin bağımsızlık iradesini en iyi şekilde gösteren 1 Mart Bağımsızlık Hareketi'nin öncesi ve sonrasındaki Koreli kadınların vatanperverlik faaliyetleri incelenmiş, bu hareketin milli şuurun yeniden canlandırılmasında ne gibi etki sağladığı değerlendirilmiştir. 1 Mart Bağımsızlık Hareketi’nden sonra Kore kadınlarının milli anlayışı ve milli egemenliğe dayanan vatansever düşünceleri, onların faaliyetlerini doğrudan etkileyerek, Kore tarihinde kadınlara yönelik bakış açısının değişmesini sağlamıştır. Ayrıca milli irade ve bilinç, bu hareketi sonrası Kore kadınlarının sürdürdüğü bağımsızlık hareketine manevi bir dayanak oluştururken, eğitim ve ekonomiyi geliştirme gibi konular üzerinde ilerlemeler sağlanmıştır. Koreli kadınların, 1 Mart Hareketin öncesinde de çağdaşlaşma ve ulusun kurtuluşu ile bağlantılı faaliyetlerde bulunmuştur. Fakat bu hareket sırasında Koreli kadınların milli kimliğindeki yeni bir algıları ulusal güç olarak ciddi şekilde değişmiştir. Tüm zor şartlara rağmen Kore'de ve yurt dışında yaşayan kadınların vatanseverlik faaliyetlerini sonuna kadar sürdürerek anavatanı için mücadele etmesi kadınların değerini ortaya çıkarmıştır. Neticede Kore Kadın Tarihi içindeki bu faaliyetlerin öneminin kadınlara güçlü bir ulusal kimlik ve vatanseverlik duygusu sağlamak olduğu anlaşılmaktadır.

Böylece Kore tarihindeki kadınlar, özellikle erkek merkezli geleneksel yaşam tarzı içinde olmalarına rağmen devletin varlığını sürdürebilmesi ve kendi özgür hayatları için aktif rol oynamıştır. Kadınların bu rolü, buhranlı dönemde bağımsızlığın kazanılması yolunda vazgeçilmez temel bir unsur olarak düşünülmektedir. Neticesinde Japonların zorbalıklarına maruz kalmalarına rağmen vatanseverlik şuurunu yitirmemişler aksine artırmışlardır. Diğer yandan ulusal hareket altında, kadınların da erkeklerle beraber ülkeyi kurtarma hareketine katılması kadın erkek eşitliği bilincinin gelişip olgunlaşmasını sağlamıştır. 
Bu çalışma, çağdaş Kore tarihinde Koreli kadınların milli hareketiyle ilgili akademik çalışma olması açısından Türkiye'de ilk olup ilerleyen zamanlarda daha detaylı araştırmalar yapılması için bir adım olma özelliği taşımaktadır. Bu çalışmada sadece Koreli kadınların milli hareketi ve vatanseverlik faaliyetleri değerlendirilmiştir. Fakat, Türk kadınının Milli Mücadele döneminde benzer hareket ve faaliyetleri olduğu görülmekte ve sonraki çalışmalarda iki ülke kadınlarının modernleşme sürecinde gelişen milli mücadele hareketinin mukayeseli olarak değerlendirilmesi planlanmaktadır. Dış güçlerin saldırısına uğrayıp bağımsızlıklarının risk altında olduğu dönemde geleneksel ve erkek egemen toplum yapısında Kore ve Türk kadınının milli şuur ve kurtuluş hareketi oluşumunu güçlendirmelerindeki tarihsel rolü üzerine yeniden odaklanılması gerektiği düşünülmektedir. Kore ve Türk kadınının milli mücadele hareketi, moderniteyi kabul ederek toplumu yeniden inşa eden ulusal bir hareket haline gelmiştir. Kore ve Türk kadının milli mücadeledeki rolü dünya çapında takdire şayan bir başarıdır.

Eğitim ve aydınlanma konuları temelinde Kore kadınının vatanseverlik mücadelesine odaklanılmış olan bu çalışmanın ardından yapılacak çalışmada iki ülke kadınının silahlı milli mücadelesinin de incelenmesi ve milletin en zor zamanında gösterilen kadın milli hareketinin önemi ve özelliklerinin kapsamlı bir şekilde incelenmesi planlanmaktadır. Her iki ülkede de kadınlar dış güçlere karşı gerçekleşen milli mücadele hareketinin ayrılmaz bir parçası olmuş, erkeklerle eşit şekilde silahlı ayaklanmalara katılmış, demokrat hükümetin kurulmasına ve siyasi direniş çabalarına önderlik eden örgütler kurmuşlardır. Uluslararası toplumların ilgisini de çeken bu durumun, Kore ve Türk milli bağımsızlık hareketinin önemli bir özelliği olduğunu söylemek mümkündür.

Hakem Değerlendirmesi: Dış bağımsız.

Çıkar Çatışması: Yazar çıkar çatışması bildirmemiştir.

Finansal Destek: Bu çalışma, Kore Cumhuriyeti Eğitim Bakanlığı ve Kore Çalışmaları Akademisi'ndeki Kore Çalışmaları Teşvik Hizmeti aracılığıyla Kore Çalışmaları Tohum Programı tarafından desteklenmiştir. (AKS-2018-INC-2230009).

Peer-review: Externally peer-reviewed.

Conflict of Interest: The author has no conflict of interest to declare.

Grant Support: This work was supported by Seed Program for Korean Studies through the Ministry of Education of Republic of Korea and Korean Studies Promotion Service at the Academy of Korean Studies (AKS-2018-INC-2230009)

\section{Kaynakça/References}

Ahn, Min-jung, "Joseon Döneminde Kadının Ahlâki Eğitimi Araştırması” (조선시 대 여성 윤리 교육 연구), Yüksek Lisans Tezi, Busan Üniversitesi Eğitim Fakültesi Etik Eğitimi Bilim Dalı, Busan, 2008

Andrew C. Nahm, Çev, Ali Rıza Balaman, Kore Tarihi ve Kültürü (Introduction to Korean History and Culture), İzmir: E.Ü. Basımevi,1998

Cha, Sung-hwan, Kore Din İdeolojisinin Sosyal Anlaylşı (한국종교사상의 사회학적 이해), Seul: Munhakkwa Jisungsa Yayınları, 1995

Choi, Sook-ryun ve Jeong, Se-hwa, Uygarlı̆̆ın Geliştiği Zamanda Kore Kadınlarının Çağdaş Anlayışının Oluşmasl(문화 발전기와 한국 여성들의 근대화 인식의 형성), Kore Kültür Araştırma Merkezi, Seul: 1976, 21 
Jeong, Eun Kyung, Kore Milliyetçiliği-Kore'de ve Türkiye'de Milliyetçilik Anlayışlarının Gelişme Süreçleri (1910-1945), İstanbul: Likya Yayınları, 2016

Jeong, Hye Joong, Metodist Piskoposluk Kadın Derneği ve Ewha Koleji(미국 북감리교 여성 해외선교부와 이화학당 대학과), Yeosunghak Nonjip, Vol.36 (2), 3-29. Seul: Ewha Üni.Yeosung Araştırma Merkezi, 2019

Kim, Jong Soo, Kore Tarihi Dersi(한국사 강의), Seul: Hanwool Yayınları, 1989

Lee, Mee-lim, “Wijeongcheoksa Düşüncesi ve Modern Milliyetçiliği: Hwaseo Lee Hang Lo’nun Milliyetçilik Anlayış1 İncelemesi” (위정척사 사상과 근대 민족주의: 화서 이항로의 민족의식에 관한 연구), Kore Cheolhak Nonjip, Vol.11, 29-50. Seul: Kore Felsefesi Araştırma Yayınları, 1999

Lee, Yoon Hee, "Kore Bağımsızlık Hareketi ve Kadınların Rolü (한국독립운동과 여성의 역 할)," Kyunghee Sahak, Vol. 21, Seul: (1997): 125-140

Lee, Se-gwon, Donghak Düşüncesi(동학 사상), Seul: Neolhaneol Yayınları, 2002

Lee, Nan-su, "Dasan, Kadın gözünden kadını çizdi” (다산, 여성의 눈으로 여성을 그리다), Konfüçüsçülük Düşünce Kültür Araştırmasl, no. 53, Seul: Konfüçyüs Enstitüsü, 2013,143-174

Park, Chan-Sung, Milliyetçilik Çağı - Japon Egemenliği Altındaki Kore Milliyetçiliği (민족주의의 시대일제하의 한국 민족주의), Seul: Kyungin Kültür Yayınları, 2007

Park, Chan-sung, Kore Modern Siyasi Tarihi araştırması (한국 근대 정치사상사 연구), Seul: Yeoksa Bipyungsa Yayınları, 1992

Park, Yong-ok, "Devlet Borç Ödeme Hareketine Kadınların Katılması" (국채보상운동에의 여성 참여), Sachong vol: 12, Seul: Koryo Üni. Yayınları, 1968, 65-84

Park, Yong-ok, Kore Kadınının Japon Karşıtı Hareketinin Tarihi Araştırması(한국여성 항일 운동사 연구), Seul: Jisik Saneopsa Yayınları, 1996

Park, Yong-ok, “ABD’deki Koreli Kadınların Bağımsızlık Hareketinin Desteklenmesi Hakkında bir Araştırma” (미주한인여성단체의 광복운동 지원 연구), Jindan Hakbo Vol.78 (1994), 254-282

Park,Yong-ok "1 Mart Öncesi Kadın Hareketi"(3.1 운동 이전의 여성운동), 1 Mart 50. Yıldönümü Anma Tezi, Seul: Don-A Yayınları (1969), 73-89

Shin, Yong-ha, Doklip Hyeop-hwe Arştırması I (독립협회연구 I), Seul: Iljokak Yayınları, 2006

Smith, D. Anthony. The Ethnic Origin of Nations, New York: Basil Blackwell Ltd, 1986

Yoo, Hyung-won, Çev, Kang, Man-gil, Kore'nin Silhak Düşüncesi(한국의 실학 사상), Seul: Samsung Yayınları, 1989

Daehan Günlük Gazetesi(대한매일 신보), 21 Şubat 1907

Dong-A Gazetesi(동아일보), 5 Nisan 1921

Dong-A Gazetesi, (동아일보), 5 Temmuz 1921.

Dong-A Gazetesi (동아일보), 26 May1s 1920.

Dong-A Gazetesi(동아일보), 1 Haziran 1920.

Dong-A Gazetesi(동아일보), 10 Haziran 1920.

Dong-A Gazetesi(동아일보), 25 Haziran 1920.

Dong-A Gazetesi(동아일 보), 1 Temmuz 1920.

Dong-A Gazetesi(동아일보), 25 Şubat 1923

Dong-A Gazetesi(동아일보), 16 Temmuz 1923 
